\title{
The Determination of the Shelf Mass in the Universal Shelving Stacker by Measuring the Frequency Converter Torque Generating Current of the Main Drive
}

Pavol Kollár ${ }^{1}$, Yuri Nikitin ${ }^{2}$, Martin Straka ${ }^{3}$

${ }^{1}$ Department of Electrical Engineering and Mechatronics, Faculty of Electrical Engineering and Informatics, Technical university of Kosice. Letna 9, 04200 Kosice, Slovak Republic. E-mail: pavol.kollar@tuke.sk

${ }^{2}$ Department of Mechatronic Systems, Kalashnikov Izhevsk State Technical University, "Mechatronic Systems" Department, Izhevsk, Russia. E-mail: doc_nikitin@mail.ru

${ }^{3}$ Logistics Institute of Industry and Transport, Faculty of Mining, Ecology, Process Control and Geotechnology, Technical university of Kosice, Park Komenskeho 14, 043 84, Kosice. Slovak Republic. E-mail: martin.straka@tuke.sk

The correct determination of the shelf mass including content is very important for the proper function of a universal shelf stacker (USS) drives life and construction USS so that these elements were not overloaded. Weighing can be done by direct methods using various sensors tension and compression but also the indirect method, by the torque sensing of current frequency converter, which controls the speed of the three-phase asynchronous motor. This method does not require any additional construction or adaptation or additional sensors or electronic evaluation system power operation. Weighting method of shelf in USS is based on the fact that the torque converter current is proportional to the sum of the weight of the shelf and the extractor and its value provides almost every frequency converter. In contrast to the direct weighing method of the shelf it is obvious economic advantage of this method and the accuracy is sufficient for the operation of USS.

Keywords: Indirect measuring, Stacker, Warehousing, Weighting

\section{Acknowledgement}

Publication has been created with the support of VEGA grant agency, in the framework of grant task VEGA 1/0036/12 „Methods development and new approaches to design of input, interoperable and output warehouses and their location in mining, metallurgy and building industries".

\section{References}

[1] MANZINI, R. et al. (2012). Warehousing in the Global Supply Chain: Advanced Models, Tools and Applications for Storage systems. p. 483. Springer-Verlag London Limited, London.

[2] VAN DEN BERG, J.P., GADEMANN, A.J.R.M. (1999). Optimal routing in an automated storage/retrieval system with dedicated storage, In: IIE Transactions, Vol. 31, No. 5, pp. 407-415.

[3] PODANÝ, J., MOLOTOVNÍK, A. (2013). 3D Measurement of Surface Texture Parameters, In: Manufacturing technology, December 2014, Vol. 14, No 4, pp. 596 - 600.

[4] KOLLAR, P. (2014). Analýza možných hardvérových a softvérových riešení použitel’ných pre riadenie univerzálneho policového zakladača, In: Aimagazine automotive industry, Vol. 7, No. 3, pp. 84-85.

[5] ZOLOTOVÁ, I., MIHAL', R., HOŠÁK, R. (2013). Objects for Visualization of Process Data in Supervisory Control, In: Aspects of Computational Intelligence: Theory and Applications, pp. 51-61., Springer-Verlag, Berlin Heidelberg.

[6] ABRAMOV, I.V., NIKITIN, Yu., ABRAMOV, A.I., SOSNOVICH, E.V., BOŽEK, P. (2014). Control and diagnostic model of brushless DC motor, In: Journal of Electrical Engineering, Vol. 65, No. 5, pp. 277- 282.

[7] BOŽEK, P., POKORNÝ, P. (2014). Analysis and evaluation of differences dimensional products of production system, In: Applied Mechanics and Materials, Vol. 611, pp. 339-345.

LOZHKIN, A., ABRAMOV, I.V., BOŽEK, P., NIKITIN, Yu. (2014). The issue of calculating elliptic trajectories, In: Manufacturing technology, Vol. 14, No. 4, pp. 561-566. 